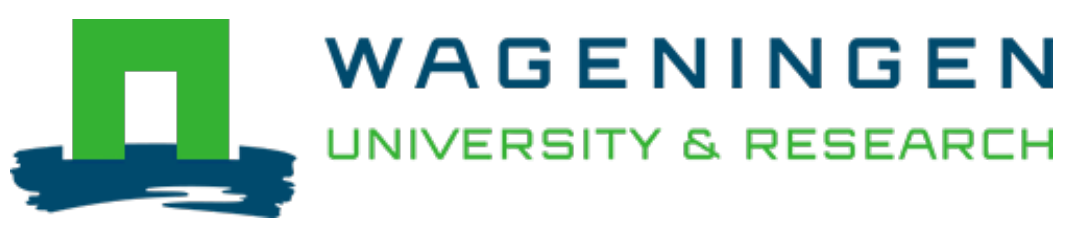

\title{
Individual competencies for managers engaged in corporate sustainable management practices
}

\author{
Journal of Cleaner Production \\ Wesselink, R.; Blok, V.; Leur, S.; Lans, T.; Dentoni, D. \\ https://doi.org/10.1016/j.jclepro.2014.10.093
}

This article is made publicly available in the institutional repository of Wageningen University and Research, under the terms of article $25 \mathrm{fa}$ of the Dutch Copyright Act, also known as the Amendment Taverne. This has been done with explicit consent by the author.

Article 25 fa states that the author of a short scientific work funded either wholly or partially by Dutch public funds is entitled to make that work publicly available for no consideration following a reasonable period of time after the work was first published, provided that clear reference is made to the source of the first publication of the work.

This publication is distributed under The Association of Universities in the Netherlands (VSNU) 'Article $25 \mathrm{fa}$ implementation' project. In this project research outputs of researchers employed by Dutch Universities that comply with the legal requirements of Article $25 \mathrm{fa}$ of the Dutch Copyright Act are distributed online and free of cost or other barriers in institutional repositories. Research outputs are distributed six months after their first online publication in the original published version and with proper attribution to the source of the original publication.

You are permitted to download and use the publication for personal purposes. All rights remain with the author(s) and / or copyright owner(s) of this work. Any use of the publication or parts of it other than authorised under article $25 \mathrm{fa}$ of the Dutch Copyright act is prohibited. Wageningen University \& Research and the author(s) of this publication shall not be held responsible or liable for any damages resulting from your (re)use of this publication.

For questions regarding the public availability of this article please contact openscience.library@,wur.nl 


\title{
Individual competencies for managers engaged in corporate sustainable management practices
}

\author{
Renate Wesselink $^{\mathrm{a}, *}$, Vincent Blok ${ }^{\mathrm{b}, 1}$, Sebastiaan van Leur ${ }^{\mathrm{b}, 2}$, Thomas Lans ${ }^{\mathrm{a}, 3}$, \\ Domenico Dentoni ${ }^{\text {b, }}{ }^{\text {D }}$ \\ ${ }^{a}$ Wageningen University, Education and Competence Studies, P.O. Box, 8130, 6700 EW Wageningen, The Netherlands \\ ${ }^{\mathrm{b}}$ Wageningen University, Management Studies, Social Sciences Group, P.O. Box, 8130, 6700 EW Wageningen, The Netherlands
}

\section{A R T I C L E I N F O}

\section{Article history:}

Received 15 October 2013

Received in revised form

30 October 2014

Accepted 30 October 2014

Available online 10 November 2014

\section{Keywords:}

CSR competencies

CSR managers

CSR practices

Sustainability competencies

\begin{abstract}
A B S T R A C T
Corporations increasingly acknowledge the importance of sustainable practices. Corporate social responsibility is therefore gaining significance in the business world. Since solving corporate social responsibility issues is not a routine job, every challenge in corporate social responsibility requires its own approach; and management competencies are crucial for designing appropriate approaches towards the realization of sustainable solutions. On the basis of seven corporate social responsibility competencies synthesized from the extant literature, this research provides an empirical analysis of which of these competencies managers need in order to achieve corporate social responsibility goals within their specific context; and at which specific stage of the implementation process. The data sources are interviews with corporate social responsibility managers - whose positions and circumstances share many similarities - at four large multinational enterprises. The empirical analysis reveals that managers undertake four corporate social responsibility core tasks: I) orientation, II) reaching common ground, III) performing pilot projects, and IV) embedding results. Within the context of the analysis, the competencies: Systems Thinking, Embracing Diversity and Interdisciplinarity, Interpersonal Competence, Action Competence, and Strategic Management were found to be necessary. The Embracing Diversity and Interdisciplinarity competence was identified as the most relevant. This study contributes to the corporate social responsibility (education) literature by introducing an empirical test of which competencies are considered necessary for managers in various stages of corporate social responsibility implementation. Linking these competencies to core tasks makes them more concrete and increases the chances of interpreting them unambiguously, which in turn can aid learning trajectories in both business and education.
\end{abstract}

๑) 2014 Elsevier Ltd. All rights reserved.

\section{Introduction}

Corporate Social Responsibility (CSR) is gaining significance in the business world, as corporations increasingly recognise the importance of ethical and responsible business practices to their survival and legitimacy (Dunphy et al., 2003). CSR is a business approach to sustainable development wherein companies

* Corresponding author. Tel.: +31 (0) 317484833.

E-mail addresses: Renate.Wesselink@wur.nl (R. Wesselink),Vincent.Blok@wur. nl (V. Blok), Sebastiaan.vanLeur@wur.nl (S. van Leur), Thomas.Lans@wur.nl (T. Lans), Domenico.Dentoni@wur.nl (D. Dentoni).

1 Tel.: +31 (0) 317483623 .

2 Tel.: +31(0) 317484833 .

3 Tel.: +31(0) 317488639 . voluntarily integrate environmental, social, and economic concerns with their business strategies - and into their interactions with stakeholders - in a quest to contribute to society in a sustainable way (Dahlsrud, 2008). This definition emphasises the voluntary nature of CSR, in that businesses engage in CSR-related activities that go beyond compliance to laws and regulations; such voluntary activities have the potential to increase the competitiveness of companies. However, since these activities can be abandoned at any time (Lozano, 2012), it is critical that they be embedded in organisations. In order to distinguish CSR from sustainability in this article, sustainability is defined as the ultimate goal of society at large (Marrewijk and Werre, 2003), whereas CSR concentrates on the contribution of companies to achieve said sustainability goal, for instance by balancing people, planet, and profit in their business practices (Kaptein and Wempe, 2002). 
However, the problem is that issues like global warming, poverty, hunger and biodiversity decline cannot be solved in an easy and unilateral way. De Colle and Henriques (2013) underline this with their statement that: "despite being well-intended, CSR standards can favour the emergence of a thoughtless, blind and blinkered mindset which is counterproductive of their aim of enhancing the social responsibility of the organisation" (p. 1). Schwartz and Tilling (2009) paint a more nuanced picture. Although they acknowledge the necessity of standards (e.g. ISO 26000), they argue that CSR standards may lead to the isolation (or decontextualisation) of complex and contested social issues, while favouring their social legitimacy. Sustainability can be enhanced by (international) standards like ISO, but sustainability challenges beyond these standards have to be approached in an interdisciplinary way (e.g., people, planet and profit); by means of collaborations between different stakeholders, in which the time dimension and the context are taken into account as well (cf. Lozano, 2008). This means that sustainability remains a challenge, where every problem or challenge should be studied in its own particular context and time frame. This complexity grows even more because multiple stakeholders like businesses, governments and non-governmental organisations (NGOs) interact in sustainability issues with often conflicting value frames and ideologies (Peterson, 2009); this explains the complexity of many CSR practices as well. This complexity is also partly recognisable in other management areas like quality management or change management, but competing interests and value frames of stakeholders are particularly at stake where it comes to CSR practices.

Dealing with CSR challenges is complex, and strategic and operational decisions have to be taken at the individual level or at the level of an internal (e.g. management team, board of directors) and/or external (e.g. multiple stakeholders) team of individuals with different backgrounds, interests and value frames. Furthermore, because of the complexity of CSR challenges, standard responses will not suffice; what worked in the past does not necessarily work for the future. This explains the importance of the individual level or, as it is framed by Hesselbarth and Schaltegger (2014), the level of "the change agent". Change agents are crucial for the development of the necessary flexibility and adaptability of businesses in dealing with new and changing sustainability challenges, it is assumed that the flexibility and adaptability of change agents lie embedded in individual competencies (Rothaermel and Hess, 2007; Wals, 2010). Although it is clear that the individual level is crucial to the achievement of sustainability goals, current research in business and management literature mainly concentrates on factors affecting or enhancing sustainability performance emanating from the institutional and organisational level (see Aguinis and Glavas, 2012 for a review; Veldhuizen et al., 2013). There is a call for studies on the contribution of individuals that may affect organisational CSR-performance (Aguinis and Glavas, 2012). In educational literature (i.e. education for sustainable development), the importance of the individual level is already recognized and better researched.

In Dentoni et al. (2012), CSR competencies in the business context are summarised by making use of existing sets of CSR and sustainable development (SD) competencies provided, for instance, by De Haan (2010) and Wiek et al. (2011). In general, these sets of competencies find their origins in educational literature and are based on literature reviews; without hardly any verification whether or how these competencies are connected with managerial CSR tasks. The goal of this paper is to empirically explore the competencies identified in the extant literature as to which of them enable managers to fulfil core tasks of CSR implementation in a specific business context. Relative to the existing literature then, this research introduces and applies a method for empirically assessing CSR competencies in cases where CSR practices are implemented in other settings. To the best of the authors' knowledge, this is the first study analysing the links between CSR competencies and core tasks of CSR implementation in a business context. The first research question of this paper therefore is: 1) Which managerial CSR competencies identified in the extant literature can be connected to CSR managers' core tasks in CSR implementation? An additional research question has to be raised to answer this question, because competencies get more meaningful when related to the context in which they are performed (Mulder et al., 2005). The second research question is: 2) What core tasks of CSR implementation can be identified for CSR managers operating in a business context? Since this article concentrates on the business context, in the remainder of this article sustainability and CSR are used interchangeably to characterize the ongoing process within organizations to realise sustainable business practices.

This research is relevant from a scientific point of view because it is interesting to know which competencies really matter in CSR implementation practices, as empirical findings about what is required of the sustainability professionals are still limited (Hesselbarth and Schaltegger, 2014). Furthermore, linking competencies with core tasks makes it possible to operationalise competencies in a more concrete way, which is necessary as indicated by Adomßent et al. (2014). On the basis of several articles within the framework of Education for Sustainable Development (ESD), they concluded that it is still necessary to operationalise competencies for measurement (i.e. assessment instruments) and educational purposes (i.e. education programmes). The latter is also important from a managerial point of view. The identified competencies, accompanied by core tasks, may enhance human resource practices (e.g. selection, development, assessment) and the development of these practices in the business (education) context.

The paper is structured as follows: first a theoretical framework for CSR competencies is presented, followed by a method section in which the methods applied are elaborated upon. Finally, the findings, conclusion and discussion are presented.

\section{Theoretical framework}

In this section the theoretical underpinnings concerning competencies are presented. The first part concerns itself with competencies in general while the second part discusses competencies specifically applicable to CSR.

\subsection{Competencies}

In education, as well as in the corporate world, the term competencies is used as a vehicle for communicating about performance and learning processes of individuals (Mulder, 2001). Boyatzis (1982) and McLagan (1989) were the first to link the practice of human resource management to development in organisations. Competencies are seen as useful (e.g., Dubois and Rothwell, 2004; Lievens et al., 2004), since they can be utilized in strategic workforce planning, selection, training and development, performance management, succession planning, and motivation and rewarding. Using competencies in organisations has benefits for both organisation and employee. The former is able to align its strategic goals with the goals of the employees, and the latter experiences more transparency (Mulder, 2001). Nonetheless, the concept of competence has been applied in widely differing ways in different countries (Gonczi, 1994), in different disciplines, and at different times. It is this widespread use that is one of the major pitfalls in working with competencies (Biemans et al., 2004). In order to fully understand what is meant by competence in this 
study, the researchers think it is necessary to make abundantly clear how to define the concept.

One can distinguish three main conceptualisations of competence: behaviouristic, generic and holistic (Biemans et al., 2004; Sandberg, 2000). In the behaviouristic conceptualisation competencies are described as observable behaviours (no attention is paid to the individuals' input, only the output is studied) associated with the completion of each small task (Gonczi, 1994). In the generic conceptualisation of competence, which was formulated as a response to the behaviouristic approach, competencies are personal qualities (character traits included) that distinguish average performers from excellent performers (Eraut, 1994). While the context is taken into account at first, through the identification (critical incidents), it gets lost again because this approach attempts to arrive at generic descriptions. Currently, Biemans et al. (2004) indicate that most interpretations of competencies are derived from the holistic conceptualisation. Within the holistic tradition, the concept of competence is defined as follows: "Competence is the integrated performance-oriented capability of a person or an organisation to reach specific achievements. These capabilities consist of clusters of knowledge structures and also cognitive, interactive, affective and where necessary psycho-motoric skills, and attitudes and values, which are conditional for carrying out tasks, solving problems and effectively functioning in a certain profession, organisation, position and role" (Mulder, 2001, p.76). Hodkinson and Issitt (1995) distinguish two dimensions of holism. The first dimension concerns the integration of knowledge, skills and attitudes that are meaningful to someone who is (becoming) a practitioner. The second dimension of holism relates to the interrelatedness with the context; competencies can only be displayed in a context by taking core tasks or roles into account.

The aforementioned holistic conceptualisation of competence is adopted in this article, because this conceptualisation is based on the observation that competence only acquires meaning within a certain context, where professionals interact with one another. Furthermore, it acknowledges that competence is related to the notion of situated cognition: "Knowledge is situated, being in part a product of the activity, context, and culture in which it is developed and used" (Brown et al., 1989, p. 32). The conceptualisations of competence in the behaviouristic and generic traditions fall short in addressing the developmental and situated nature of professional practice (Billett, 1994), and situated professionalism (Mulder, 2014). Mulder et al. (2005) have emphasised the importance of analysing meaningful combinations of core tasks before competencies can be identified or selected; said core tasks represent the situation in which the competencies are put into practice. Taking core tasks as a starting point ensures that the situation (i.e. the job and organisation) in which the competencies are to be applied is taken into account. In this approach, competence modelling consists first of a task analysis (from the perspective of the work that has to be done to ensure the connection with the situation) and second a competence analysis (from the perspective of the worker who has to do the work) (Sandberg, 2000). This corresponds with what Cheetham and Chivers (1996) have called the functional approach.

\subsection{CSR competencies}

Over the past few years, individual competencies for sustainable development have received increasing attention in sustainability literature. Significant progress has been made in conceptualising competencies for sustainable development, predominantly in the world of education (e.g., Barth et al., 2007; De Haan, 2010; Wiek et al., 2011). Steps have been taken in the corporate world as well; Willard et al. (2010) provide us with an overview of the competencies of sustainability managers. Within the educational tradition, two recent studies should be singled out for their empirical approach. In the first place, the study by Rieckmann (2012). He identified three important competencies (labelled as key competencies) for higher education: systemic thinking and handling of complexity, anticipatory thinking, and critical thinking. The significant value of this paper is the way it utilises its empirical basis (i.e. by questioning international experts in the field of SD) to achieve international agreement in the debate concerning the most important key competencies for SD. Secondly, the work of Hesselbarth and Schaltegger (2014). On the basis of MBA alumni's experiences, they empirically linked sustainability competencies with situated duties and activities. They created a so-called competency matrix for change agents in sustainability, in which they propose a structure of basic components for postgraduate education in sustainability management. To complement and advance on this strand in the literature, this research introduces and applies a method for providing empirical evidence on CSR competencies from the perspective of managers undertaking CSR implementation practices.

In this study competencies are linked to core tasks of a job, while practitioners (CSR managers) provide the empirical basis; the situatedness is taken into account. In this way, competencies might grow more meaningful (according to Mulder, 2014) and that, in turn, might lessen the differences of opinion about the proper interpretation of the competencies required for sustainability. The aim of this article therefore - as the introduction already stated - is to relate CSR (key) competencies to the core tasks of CSR managers in everyday practice, in order to get a better sense of the desired competencies with the aim of increasing meaningfulness and doing away with misinterpretations.

Dentoni et al. (2012) made use of existing frameworks for SD and CSR competencies. They used De Haan (2010) and Wiek et al. (2011) as starting points, complemented by sets of SD competencies reported by Ellis and Weekes (2008), Mogensen and Schnack (2010, 1996) and Wilson et al. (2006). From this they composed a list of seven competencies for sustainability. This list is a comprehensive overview of SD competencies up to 2011 and was taken as a starting point for this study. But neither the list by Dentoni et al. (2012), nor the lists sourced from other authors (i.e. De Haan, Wiek et al.) view competencies in relation to the tasks or job duties of sustainability managers in professional practice. This stems from the predominantly educational purposes and backgrounds of said sets of competencies.

Dentoni et al. (2012) composed a framework consisting of seven competencies required for professionals who are actively involved in dealing with sustainability in their work environment:

1. Systems thinking competence: the ability to identify and analyse all relevant (sub)systems across different domains (people, planet, profit) and disciplines, including their boundaries. Systems thinking competence is the ability to understand and reflect upon the interdependency of these (sub)systems, including cascading effects, inertia, feedback loops and accompanying cultures (Wiek et al., 2011).

2. Embracing diversity and interdisciplinarity competence: the ability to structure relationships, spot issues, and recognise the legitimacy of other viewpoints in business decision making processes; be it about environmental, social and/or economic issues. It is the ability to involve all stakeholders and to maximise the exchange of ideas and learning across different groups (inside and outside the organisation) and different disciplines (De Haan, 2010; Ellis and Weekes, 2008; Wilson et al., 2006).

3. Foresighted thinking competence: the ability to collectively analyse, evaluate, and craft "pictures" of the future in which the impact of local and/or short term decisions on environmental, 
social and economic issues is viewed on a global/cosmopolitan scale and in the long term (Wiek et al., 2011).

4. Normative competence: the ability to map, apply and reconcile sustainability values, principles and targets (Wiek et al., 2011).

5. Action competence: the ability to actively involve oneself in responsible actions for the improvement of the sustainability of social-ecological systems (De Haan, 2010; Mogensen and Schnack, 2010; Schnack, 1996).

6. Interpersonal competence: the ability to motivate, enable, and facilitate collaborative and participatory sustainability activities and research (Wiek et al., 2011).

7. Strategic management competence: the ability to collectively design projects, implement interventions, transitions, and strategies for sustainable development practices. This domain involves skills in planning (e.g., design and implement interventions), organising (arranging tasks, people and other resources), leadership (inspiring and motivating people) and control (e.g., evaluating policies, programmes and action plans) (De Haan, 2010; Wiek et al., 2011).

The following section describes the empirical analysis methods used in this research.

\section{Methods}

To answer the research questions, existing interview data from a prior research project was used. Analysing existing data for another purpose - i.e. secondary data analysis - involves pursuing a research interest which is distinct from that of the original work; be it a new research question or an alternative perspective on the original question (Hinds et al., 1997).

In this case, the stated goal of the prior research project was learning how companies engage with stakeholders - such as NGOs or governments (Selsky and Parker, 2005) - and integrate knowledge of sustainable development into the organisation (Veldhuizen et al., 2013). Within the context of this prior project, the interviews described how managers undertook CSR activities in a multistakeholder collaboration context; said project focused on the company involvement in cross-sector partnerships within the framework of sustainability. The analysis put forward in this article, however, focuses on the core tasks of individual professionals involved in the implementation of sustainability. The fact that stakeholder involvement is crucial for working on CSR challenges has already been pointed out in the theoretical section by referring to Peterson (2009); social responsibility implies responsiveness to the expectations of stakeholders. All in all, the reutilisation of the existing interview data for pursuing answers to other, albeit closely related, research questions was deemed legitimate. It adheres to what has been called a new perspective focus (Heaton, 2002).

Heaton (2002) summarises four methodological and ethical concerns to be taken into consideration when utilising secondary data analysis. The first issue concerns compatibility of the data. To what extent are the data amenable to the goals of the secondary analysis? In this case, all of the interviews were aimed at the analysis of organisational drivers for sustainable development. It was therefore considered to be compatible. The second issue reported by Heaton (2002) concerns the position of the secondary analyst. The requirement that was formulated to satisfy this issue is that the secondary analyst has access to the primary data. In the current study, one of the analysts involved in the secondary data analysis was also involved in collecting and analysing the primary data for the original study. The third issue concerns the transparency with which the primary data were gathered. In this study, the design, methods, and issues involved are fully reported on so as to be as transparent as possible. Finally, Heaton (2002) brings forward the ethical issue. Where sensitive data is involved, to what extent does secondary analysis violate the contract made between the subjects and the primary researchers? In this case the topic of the interviews was sustainability as well, so in that sense the contract is not deemed to have been violated.

The original research was based on case studies. Cases were selected on the basis of theoretical sampling (see Veldhuizen et al., 2013 for more details on sampling and criteria). The case study method is also appropriate for this current study because the context in which the managers operate is crucial to the tasks they perform and consequently to the competencies they need (Yin, 2002). Furthermore, the case study method lends itself to theoretical development (Yin, 2002). The nature of the study is qualitative, in the sense that in-depth interviews of four managers were used for this research. This research has an explorative nature because, to the knowledge of the researchers, it is the first time the theoretical (key) competencies are defined in relation to practical core tasks of CSR implementation.

\subsection{Sample selection \& data collection}

As part of the prior project from which the interviews constituting the database for this research are taken, between 2011 and early 2012 researchers questioned CSR managers of four of the fifty largest global agri-food MNE's. The agri-food business is a primary example of a sector where sustainability is important, given its role in food-related health crises (European Commission, 2001) and the enhancement of food safety (Hamann et al., 2011). Companies in the agri-food sector increasingly attempt to meet the expectations of their stakeholders (customers, governmental organisations, society at large) (Dentoni et al., 2012) in order to secure and enhance their license to operate (Blok et al., 2013; cf. Gunningham et al., 2004).

While in the prior research the four companies involved in CSPs were purposely selected (Veldhuizen et al., 2013), in this study it is the CSR managers that are analysed - rather than their companies - since this study's unit of analysis is the individual rather than the organization. The cases of the four managers are comparable based on the following three parameters: 1) all companies operate in the same industry (food manufacturers buying raw agricultural products); 2) all companies are comparable in size - being large multinationals procuring similar agricultural products from developing countries and emerging economies - and facing similar sustainability problems (similar in terms of global scale and complexity of the issues at hand); and 3) all CSR managers work at the decisionmaking European headquarters of their respective companies; all of which are based in the Netherlands.

The interviews were held with CSR managers (responsible for sustainability and CSR), were semi-structured in nature, and focused on understanding how they dealt with multiple stakeholders in the process of CSR implementation. Indirect questioning techniques were utilised to learn as much as possible from the subjects, while at the same time attempting to minimise social desirability bias (Fisher, 1993). The managers were asked to: "describe a set of CSR initiatives undertaken by themselves as their companies' CSR representatives with stakeholders over time, both within and outside CSP for SD".

\subsection{Data analysis}

Although multiple cases are used, it is not the aim of this study to compare said cases. The cases are used to describe the tasks and activities of the CSR managers in their real-life context. The data gathered in the four cases are analysed by means of a descriptive method (Yin, 2002). 
The analysis of the interview data involved three steps and consisted of a combination of inductive and deductive methods. All steps were undertaken with three researchers (in each step the same researchers were involved) in order to establish intersubjectivity.

The first step consisted of the identification of core tasks. As explained above, a core task is defined as an important meaningful task in practice (Mulder et al., 2005). Core tasks undertaken in the sustainability initiatives were identified from the raw data in an inductive way. The first step was marking those excerpts from each interview that represented relevant process steps and activities in moving towards sustainability. These excerpts were subsequently labelled; the labels emerged bottom up while selecting the excerpts. Initially, each researcher examined the interview transcripts individually and, subsequently, identified excerpts and coded these excerpts with labels (open coding; Glaser and Strauss, 1967). Then the different lists of excerpts and accompanying labels were compared by the group of researchers as a whole and integrated into one list by means of axial coding (Glaser and Strauss, 1967); eventually ending up with a list of core tasks. Different rounds of coding were needed to attain sufficient intersubjective agreement (Glaser and Strauss, 1967). The result was a list of 19 core tasks to be explored and have their interrelationship examined. This resulted in four sets of core tasks arranged in chronological order: I) Orientation, II) reaching common ground, III) performing pilot projects, and IV) embedding results.

The second step was to identify labels for the competencies in order to make them, as formulated within the theoretical framework, less abstract. Based on the description of the competencies by Dentoni et al. (2012), and an existing questionnaire based on those same competencies (Lans et al., 2014), the seven competencies were provided with labels representing underlying performance criteria. This resulted in a total set of 70 labels for all CSR competencies (see appendix A). This step had a deductive character; the theory-based competence descriptions are rendered more concrete by means of these labels.

In the third and final step, the outputs of step 1 and 2 were matched. In practice this meant that the relationship between the sets of core tasks (step 1) and the competencies (step 2) were assessed. This relationship was assessed based on the overlap of both sets of concrete labels. Each researcher initially examined the relationship between the labels of the competencies and labels of the core tasks on his/her own. Subsequently, the similarities and differences were identified by the researchers as a group. Since coding relations between core tasks and competencies is mainly interpretative work (Glaser and Strauss, 1967), three rounds of discussion were needed to attain intersubjective agreement. The percentage of labels that straddled both constructs was called the overlap (see Table 3). If more than $50 \%$ of the labels of the competencies and the core tasks showed overlap, there was considered to be a relationship between competence and core task. The percentage used is relatively low, owing to the explorative character of this study, but is considered appropriate at this stage.

\section{Findings}

The findings section is divided into two parts (respectively, the results of step 1 and 2) after which these two parts are integrated (step 3). The first part concerns the core activities of implementing CSR divided among four phases. In Table 1, the four sets of core tasks are shown alongside the individual core tasks. These sets of core tasks are: I) Orientation, II) Reaching common ground, III) Performing pilot projects and IV) Embedding results. Each set consists of three to six core tasks and each core task is described in the table.
Table 1

Sets of core tasks and separate core tasks.

\begin{tabular}{ll}
\hline Set of core tasks & Core tasks \\
\hline I. Orientation & 1. Sustainability thinking \\
& 2. Analysing systems \\
& 3. Identifying consumer needs \\
& 4. Willingness to change \\
& 5. Weighing stakeholders \\
& 6. Strategic decision making \\
II. Reaching common ground & 7. Initiating changes \\
& 8. Building openness and trust \\
& 9. Sharing objectives \\
10. Balancing interests \\
11. Operational decision making \\
12. Collaborating \\
13. Knowledge sharing and integration \\
14. Project management \\
15. Supply chain orientation \\
16. Disseminating output \\
17. Creating project ownership/empowering \\
internal change agents \\
18. Integrating approaches \\
19. Marketing
\end{tabular}

The second part of the results consists of the competencies and accompanying labels. In step 2, for each competence between 5 and 19 labels were identified. Appendix A shows the entire set of labels. In Table 2, the accompanied core tasks are shown per competence (i.e. systems thinking competence) if the overlap between the labels representing competencies and the labels representing core tasks was $50 \%$ or more.

Table 2 shows us that the labels of five competencies show sufficient overlap with labels of core tasks. These competencies are: Systems thinking, Embracing diversity and interdisciplinarity, Interpersonal, Action and Strategic management. The competencies Normative and Foresighted thinking are not linked to core tasks during the analysis. Except for Action, all competencies are deemed necessary in more than one or even more than two sets of core tasks. In the first set of core tasks (Orientation) three competencies are identified as necessary: Systems thinking, Embracing diversity and interdisciplinarity, and Strategic management. In set II (Reaching common ground), there are also three competencies that are identified as necessary for performing the core tasks: Embracing diversity and interdisciplinarity, Interpersonal, and Action. In set III (Performing pilot projects), there are even four competencies that are considered necessary: Systems thinking, Embracing diversity and interdisciplinarity, Interpersonal, and Strategic management. In set IV (Embedding results), two competencies are considered necessary: Embracing diversity and interdisciplinarity, and Interpersonal. In all sets the Embracing diversity and interdisciplinarity competence is viewed as vital to the core tasks of implementing CSR; Table 3 provides an overview. In this table the relationship between the competencies and the sets of core tasks is shown. Where competencies were related to one or more of the core tasks in the sets of core tasks, a mark was placed in the corresponding box.

Reading the content of Table 3, it illustrates clearly that the this study does not identify the competencies Normative and Foresighted thinking as necessary for the realisation of CSR and that Embracing diversity and interdisciplinarity is the one that is needed in all sets of core tasks for the realisation of CSR. Furthermore, Table 3 shows that when applying the 50\% rule, the following core tasks are excluded for a lack of overlap: sustainability thinking (only $11 \%$ ), identifying consumer needs (only 20\%), collaborating (no overlap at all), disseminating output (no overlap at all) and marketing (no overlap at all). This does not mean that those core tasks are unimportant; it just means that they do not relate to the competencies as put forward by theory. This indicates that other 
Table 2

Percentage of overlap between the labels of competencies and the labels of core activities.

\begin{tabular}{|c|c|c|c|c|}
\hline Competence & Core tasks (number of core task set) & $\begin{array}{l}\text { Nr. of labels per } \\
\text { competence as } \\
\text { theoretically } \\
\text { constructed (step 2) }\end{array}$ & $\begin{array}{l}\text { Nr. of labels of this } \\
\text { competence affiliated } \\
\text { with the core activities } \\
\text { (step 3) }\end{array}$ & $\begin{array}{l}\text { \% Overlap of the labels } \\
\text { per competence and } \\
\text { core task (step 3) }\end{array}$ \\
\hline \multirow[t]{2}{*}{ Systems thinking competence } & 2. Analysing systems (I) & 12 & 12 & $100 \%$ \\
\hline & 15 Supply chain orientation (III) & 12 & 12 & $100 \%$ \\
\hline Foresighted thinking competence & 3. Identifying consumer needs & 10 & 2 & $20 \%$ \\
\hline Normative competence & 1. Sustainability thinking & 9 & 1 & $11 \%$ \\
\hline \multirow{6}{*}{$\begin{array}{l}\text { Embracing diversity and } \\
\text { interdisciplinarity competence }\end{array}$} & 4. Willingness to change (I) & 7 & 4 & $57 \%$ \\
\hline & 5. Weighing stakeholders (II) & 7 & 7 & $100 \%$ \\
\hline & 10. Balancing of interests (II) & 7 & 7 & $100 \%$ \\
\hline & 13. Knowledge sharing and integrating (III) & 7 & 5 & $71 \%$ \\
\hline & 8. Building openness and trust (III) & 7 & 7 & $100 \%$ \\
\hline & 18. Integrating approaches (IV) & 7 & 6 & $86 \%$ \\
\hline \multirow[t]{4}{*}{ Interpersonal competence } & 9. Sharing objectives (II) & 8 & 7 & $88 \%$ \\
\hline & 10. Balancing of interests (II) & 8 & 6 & $75 \%$ \\
\hline & 8. Building openness and trust (III) & 8 & 8 & $100 \%$ \\
\hline & $\begin{array}{l}\text { 17. Creating project ownership/empowering } \\
\text { internal change agents (IV) }\end{array}$ & 8 & 4 & $50 \%$ \\
\hline \multirow[t]{2}{*}{ Action competence } & 7. Initiating changes (II) & 5 & 5 & $100 \%$ \\
\hline & 11. Operational decision making (II) & 5 & 4 & $80 \%$ \\
\hline \multirow[t]{2}{*}{ Strategic management competence } & 6. Strategic decision making (I) & 19 & 9 & $51 \%$ \\
\hline & 14. Project management (III) & 19 & 16 & $84 \%$ \\
\hline
\end{tabular}

competencies need to be identified, because the current ones cannot be linked to these core tasks.

\section{Discussion}

Within the context of this research, the competencies Foresighted thinking and Normative were not recognised in the CSR practices of the four CSR managers. This does not mean that these competencies are totally unimportant; both Rieckmann (2012) and Hesselbarth and Schaltegger (2014) provide empirical evidence for both competencies (or comparable constructs). The results of this study only indicate that those competencies are not related to the core tasks of the four CSR managers under analysis.

In other words, within the specific context of these CSR managers, Foresighted thinking does not appear to be necessary anymore. This could lead to the interpretation that Foresighted thinking is only necessary at the point in time when the decision to start working on sustainability is taken by the board of directors, while for other people within the organisation (CSR managers in this case) it is not necessary, from an organisational point of view, to think foresightedly. This possible explanation would be consistent with what is depicted by Maon et al. (2009): each phase of CSR implementation (i.e. sensitize, unfreeze, move and refreeze) demands different activities and qualities from managers and organisations. Following this line of reasoning, Foresighted thinking

Table 3

Competencies underpinning sets of core tasks for realizing sustainability.

\begin{tabular}{lllll} 
& $\begin{array}{l}\text { I } \\
\text { orientation }\end{array}$ & $\begin{array}{l}\text { II } \\
\text { reaching } \\
\text { common } \\
\text { ground }\end{array}$ & $\begin{array}{l}\text { III performing } \\
\text { pilot projects }\end{array}$ & $\begin{array}{l}\text { IV } \\
\text { embedding } \\
\text { results }\end{array}$ \\
\hline $\begin{array}{c}\text { Systems thinking } \\
\text { competence }\end{array}$ & $\mathrm{X}$ & & $\mathrm{X}$ & \\
$\begin{array}{c}\text { Embracing diversity and } \\
\text { interdisciplinarity } \\
\text { competence }\end{array}$ & $\mathrm{X}$ & $\mathrm{X}$ & $\mathrm{X}$ & $\mathrm{X}$ \\
$\begin{array}{l}\text { Interpersonal competence } \\
\text { Action competence } \\
\text { Strategic management }\end{array}$ & $\mathrm{X}$ & $\mathrm{X}$ & $\mathrm{X}$ & $\mathrm{X}$ \\
$\quad$ competence & & $\mathrm{X}$ & \\
\hline
\end{tabular}

could be relevant in the starting (sensitize) phase and lose its importance in the other phases (unfreeze, move and refreeze) where the analysed managers currently reside.

The Normative competence also went unrecognised in the specific setting of the analysed managerial CSR practices. Sustainability is undeniably a normative concept, as it does not describe the world as it is but as it should be. In the Normative competence, values, principles, goals and targets are negotiated and it includes such broad concepts as integrity, equality and justice (Wiek et al., 2011). In this respect, normative competence concerns itself with the way companies should operate. According to this view on normative competence, a plausible interpretation of this result is that managers do not recognise the Normative competence in their CSR practice because it has been internalized in their behaviour. Another, yet still plausible, interpretation is that the apparent absence of normative competence in the dataset may indicate structurally low levels of normative competence within the selected business context. This, in turn, could explain some of the conflicts between companies and NGOs with regards to value frames and trade-offs between ecological and economic interests (Peterson, 2009). In this respect, one could argue that these companies are not acting in an ethical fashion. This could, for instance, be due to a strong focus on profit maximisation. In this respect, these findings could be seen as confirmation of the classical view of the firm as non-ethical, or of the fact that these competencies are not necessary (anymore) in the phase the participating companies find themselves in.

Action competence is only recognised in relation to the second set of core tasks (reaching common ground). This could be seen as a surprising result because one would expect that the action competence might be important while performing pilot projects (III) as well. Action competence, however, means to actively involve oneself in responsible actions for the improvement of the sustainability of social-ecological systems (De Haan, 2010; Ellis and Weekes, 2008; Mogensen and Schnack, 2010). Because action competence (with labels such as: pro-activeness in decision making, taking responsibility, and perseverance of goals) concentrates on the personal involvement and personal actions of a CSR manager (De Haan, 2010) and not on the activity of other members of the company (e.g., line-managers, support staff). This may explain why action competence is in fact important for the second set of core 
tasks, namely to reach common ground. This implies that CSR managers initiate action and bring parties together when they deem it necessary.

Strategic management competence and Systems thinking competence are both identified as important to the set of core tasks Orientation (I) and Performing pilot projects (III). This can be explained by the fact that management in this first phase has to be performed mainly outside of the company (i.e. with stakeholders) and be seen within the larger context. The third set of core tasks concerns mainly internal (strategic) management. CSR managers' systems thinking focuses mainly on the product or process level. For example, systems - as described by Wiek et al. (2011) - are abstract by nature, whereas in the practice of the CSR manager systems equate to products. Both competencies are needed at two different levels which implies differing operationalisations of these competencies in relation to the different sets of core tasks.

Furthermore, Interpersonal competence is considered important in the last two sets of core tasks (performing pilot projects and embedding results). It turns out that convincing one's company's employees and managers to participate in a pilot project is of vital importance. And the execution of that core task depends heavily on the interpersonal competencies of CSR managers. After convincing the employees and management, it is important that CSR managers keep sustainability on the agenda and embed the results in daily practice. Interpersonal competencies turn out to be very important in this set of core activities as well.

Finally, the results suggest that the Embracing diversity and interdisciplinarity competence is the one that is identified as necessary for all sets of core tasks. It is relevant to all sets because the diversity of stakeholders and their values and opinions are important while also being subject to change. So, it is necessary to constantly review stakeholder opinions (internally and externally) and take those considerations into account. Interdisciplinarity is also present in all sets of core tasks. CSR managers have to cooperate with people representing different disciplines in each set of core tasks; with NGOs in the first (Orientation) phase, for example, and in later stages with representatives of internal company disciplines (in project teams with representatives from different departments, for example). In the research by De Haan (2010) interdisciplinarity is merely considered in terms of topics (poverty or economics) that have to be analysed and evaluated in the past and present. When operationalising this competence in the context of CSR managers, it mainly comes down to working with people with a different (disciplinary) background. CSR managers constantly work with groups of people from a wide range of disciplines and the composition of these groups varies in accordance with different sets of tasks. Rieckmann (2012) also confirms the significant importance of interdisciplinary work, empathy, and change of perspective; although not as one of the three most important key competencies. This might be explained by the different empirical bases (i.e. education and corporate) on which the conclusions were drawn.

It is shown that each verified competence has its own role to play in a particular set of tasks. The operationalisation of the same competence differs per set of core tasks, thus giving more in-depth understanding of what CSR competencies encompass. This makes the competencies more meaningful, comprehensible in practice and less exposed to ambiguous interpretations, which is beneficial for training and assessment purposes like ESD (Adomßent et al., 2014).

Follow-up research would necessarily need to uncover which competencies are necessary to underpin those core tasks that fell out of this study's analysis. This concerns the core tasks: sustainability thinking, identifying consumer needs, collaborating, disseminating output, and marketing. It should be possible, by means of interviews, to learn more about these core tasks and to identify the competencies they desire. This overview of competencies underpinning core tasks for implementing sustainability is therefore not complete yet. One would expect to find a competence like communicating with stakeholders outside the own organisation (O'Riordan and Fairbrass, 2013).

What do the outcomes of this study mean for (future) CSR managers; how can they develop these competencies? For them, it is important to receive feedback from other employees and reflect on their practical experiences so as to learn together from dealing with and solving CSR challenges. In the first place, the situational/ contextual aspect is very important for learning (Billett, 1994), so general approaches for teaching these competencies are less desirable. Secondly, it is extremely difficult to approach the complexity of sustainability challenges in educational settings, although research shows that higher education is making great strides towards implementing education for sustainable development (Rieckmann, 2012; Wals, 2014; Lambrechts et al., 2013). Higher education will provide students with a necessary and firm basis through the use of service learning, for example. It remains, however, necessary to implement (learning) activities in (management) practice. Learning sustainability or CSR is a continuous and collective (learning) process (cf. Blok, 2013) and those managers that are already professionals will have to develop themselves in this area. The competencies required are too complicated to develop "on the fly". Managers need discussion and feedback, to really develop and improve these competencies.

The research described in this article is an attempt to approach CSR competencies from a situated conceptualisation of competence. The next step in research would be to actually test how the competencies and core tasks relate to each other through a more quantitative approach, while the relationships that this study revealed could be tested more broadly.

The research set-up and approach chosen in this study have their limitations; the first set of limitations relates to the secondary data analysis. In the first place, although the conditions - as set by Heaton (2002) - are met, the very nature of secondary data analysis leaves it particularly susceptible to criticism and it would be most effective when combined with other approaches (Smith, 2008). In this particular case, the data were gathered with another aim, consequently there was no chance to ask further questions on the particular topic of this article and it remains unclear whether all information that the subjects had to offer about the core tasks in relation to CSR was shared. Nevertheless, one can consider this a useful exploration of introducing and applying a method for operationalising competencies and for gauging what competencies are necessary for which CSR core tasks in management practice. Secondly, the context in which the managers under analysis operate is highly specific since the four managerial cases have key common characteristics. Thirdly, uncovering managers' competencies necessary for realising CSR is considered to be quite difficult (cf. Van Kleef and Room, 2007); because asking managers for these competencies mostly ends in every competence being deemed important. Connecting the competence with core tasks and applying an indirect analysis prevents this problem. Where it comes to the purpose of operationalising the competencies, the set-up of this research appears to be sufficient and the results of this study should be seen as setting the research agenda. It is important to test the operationalisation on a larger scale, though. In relation to this, the researchers feel the choice to work with $50 \%$ overlap was justified. The purpose of this article, as mentioned before, was to explore how competencies and core tasks relate to each other, and in the opinion of the researchers a $50 \%$ overlap is considered sufficient to demonstrate a relationship. 
The second set of limitations relates to case studies. The most important shortcoming of a case study method is the seeming lack of generalisability of the outcomes (Yin, 2009). This study incorporates four cases (i.e. CSR managers) and that is a relatively small number. The extent to which the results can be generalised is to be considered limited. The results are especially valid for managers working in agri-food companies that took the decision to effect CSR (and therefore already appointed CSR managers, for example), and are in the phase of actually working on pilot projects to implement it (unfreeze stage; Maon et al., 2009). Another pitfall of the case study approach is how to ensure the consistency in the findings. To maximise robustness two measures were taken. In the first place, the interview data were collected by means of semistructured interviews, so they were comparable to a large extent. And secondly, because multiple researchers independently coded the interview data and subsequently met and came to a consensus on the emerging codes and categories, the reliability of the findings was increased (Baxter and Jack, 2008).

Finally, the role of CSR managers was central to this study. But, as the core tasks already show, the CSR managers are not the only persons involved in the implementation of CSR. The CSR managers could be identified as the "change agents" of Hesselbarth and Schaltegger (2014), but these professionals need to involve other employees within their organisations as well (in projects, for example). They are the ones who have to bring about change and ensure that CSR is an ongoing (and collective) learning process, which should eventually involve all company employees. In further research, it remains to be seen to what extent other employees within organisations need competencies and how these competencies are distributed among different groups of employees. Maybe it would be possible to identify specific competencies for specific sets of CSR core tasks and groups of employees within organisations. This would make the operationalisation of the competencies even more concrete.

\section{Conclusions}

To contribute to the theory and practice of CSR and competencies, two research questions guided this study. The first research question of this paper was: 1) Which managerial CSR competencies identified in the extant literature can be connected to CSR managers' core tasks in CSR implementation? To answer this question, an additional research question was raised, because competencies are more meaningful in relation to the core tasks (situation) in which they are performed. 2) What core tasks of CSR implementation can be identified for CSR managers operating in a business context?

Knowing that the results of research question 2 are conditional upon the results of research question 1, the conclusion to research question 2 is presented first. In total, four sets of core tasks were identified while analysing the transcripts of the interviews with CSR managers: I) orientation (6 core tasks), II) reaching common ground ( 5 core tasks), III) performing pilot projects ( 5 core tasks) and IV) embedding results ( 3 core tasks). These core tasks represent the daily tasks of CSR managers of companies that have been working on CSR for some years. Related to the first research question, the results suggest that the following competencies are to be recognised in relation to the sets of core tasks: Systems thinking, Embracing diversity and interdisciplinarity, Interpersonal competence, Action competence and Strategic management. These competencies all have a link with one or more sets of core tasks. Linking competencies with core tasks contextualises CSR competencies in CSR management practices and provides empirical evidence of the theoretically identified competencies.
The aim of this article was to explore which competencies would relate to CSR core tasks as identified in CSR managerial practice. This contributes to the literature by refining the existing CSR competencies theory with an empirical method that identifies the core tasks for CSR implementation while finding its basis in managerial practice. Future research at the individual level could benefit from applying this method to identify sets of relevant competencies and core tasks in different and broader contexts. Furthermore, the list of competencies in relation to core tasks has practical advantages for both corporate and educational practices. Connecting the competencies to core tasks makes these competencies more meaningful and opens up possibilities of operationalising these competencies. For both the educational context (development and assessment) and the management context (especially development) this gives concrete input for learning trajectories (i.e. service learning, peer feedback).

\section{Appendix A. Competencies and accompanying labels.}

\begin{tabular}{|c|c|}
\hline Competence & Labels \\
\hline $\begin{array}{l}\text { Systems thinking } \\
\text { (12 labels) }\end{array}$ & $\begin{array}{l}\text { 1. Analysing sub systems } \\
\text { 2. Analysing systems } \\
\text { 3. Cascading effects } \\
\text { 4. Causing effect relations } \\
\text { 5. Reflecting on elements of interdependency } \\
\text { 6. Identifying sub-systems } \\
\text { 7. Identifying scale } \\
\text { 8. Understanding aspects of interdependency } \\
\text { 9. Identifying systems } \\
\text { 10. Feedback loops } \\
\text { 11. Understanding scale effects } \\
\text { 12. Overview of motives }\end{array}$ \\
\hline $\begin{array}{l}\text { Foresighted thinking } \\
\quad \text { (10 labels) }\end{array}$ & $\begin{array}{l}\text { 1. Crafting pictures of the future } \\
\text { 2. Assessing effects on intergenerational equity } \\
\text { 3. Balancing local } \backslash \text { global } \\
\text { 4. Opportunities recognition } \\
\text { 5. Balancing long-term } \backslash \text { short-term } \\
\text { 6. Innovation } \\
\text { 7. Collectively evaluating pictures of the future } \\
\text { 8. Assessing unintended harmful consequences } \\
\text { 9. Collectively analysing pictures of the future } \\
\text { 10. Creativity }\end{array}$ \\
\hline $\begin{array}{l}\text { Normative } \\
\text { competence } \\
\text { (9 labels) }\end{array}$ & $\begin{array}{l}\text { 1. Ethics } \\
\text { 2. Equity } \\
\text { 3. Inter and intra generational equity } \\
\text { 4. Principles } \\
\text { 5. Accountable for decision-making } \\
\text { 6. Values } \\
\text { 7. Sustainability values } \\
\text { 8. Justice } \\
\text { 9. Socio-ecological integrity }\end{array}$ \\
\hline $\begin{array}{l}\text { Embracing diversity } \\
\text { and Interdisciplinary } \\
\text { (7 labels) }\end{array}$ & $\begin{array}{l}\text { 1. Structure relations } \\
\text { 2. Facilitating dialogue } \\
\text { 3. Stimulating exchange of ideas } \\
\text { 4. Proactivity in information exchange } \\
\text { 5. Openness to other viewpoints } \\
\text { 6. Recognition of legitimacy of different viewpoints } \\
\text { 7. Involving stakeholders }\end{array}$ \\
\hline $\begin{array}{l}\text { Interpersonal } \\
\text { competence } \\
\text { (8 labels) }\end{array}$ & $\begin{array}{l}\text { 1. Enabling collaboration } \\
\text { 2. Communicating } \\
\text { 3. Facilitating collaboration } \\
\text { 4. Empathy } \\
\text { 5. Ability to motivate collaboration } \\
\text { 6. Collaborating } \\
\text { 7. Compassion } \\
\text { 8. Negotiating }\end{array}$ \\
\hline $\begin{array}{l}\text { Action } \\
\text { competence } \\
\text { (5 labels) }\end{array}$ & $\begin{array}{l}\text { 1. Proactive in decision making } \\
\text { 2. Taking responsibility } \\
\text { 3. Perseverance of goals } \\
\text { 4. Decision initiative }\end{array}$ \\
\hline
\end{tabular}


(continued)

\begin{tabular}{ll}
\hline Competence & Labels \\
\hline & 5. Active involvement \\
management & 1. Evaluation of policies \\
(19 labels) & 2. Controlling \\
3. Collectively design interventions \\
4. Leading \\
5. Planning skills \\
6. Taking action \\
7. Inspiring \\
8. Organize \\
9. Implementing strategies \\
10. Measuring performance \\
11. Collectively implementing interventions \\
12. Evaluation \\
13. Arranging tasks \\
14. Motivating \\
15. Arranging resources \\
16. Arranging people \\
17. Designing transitions \\
18. Evaluation of programs \\
19. Evaluation of action plans \\
\end{tabular}

\section{References}

Adomßent, M., Fischer, D., Godemann, J., Herzig, C., Otte, I., 2014. Emerging areas in research in higher education for sustainable development - management education, sustainable consumption and perspectives from Central and Eastern Europe. J. Clean. Prod. 62, 1-7.

Aguinis, A., Glavas, H., 2012. What we know and don't know about corporate social responsibility: a review and research agenda. J. Manag. 38 (4), 932-968.

Barth, M., Godemann, J., Rieckman, M., Stoltenberg, U., 2007. Developing key competences for sustainable development in higher education. Int. J. Sustain. High. Educ. 8, 416-430.

Baxter, P., Jack, S., 2008. Qualitative case study methodology: study design and implementation for novice researchers. Quantitative Rep. 13 (4), 544-559.

Biemans, H.J.A., Nieuwenhuis, L., Poell, R., Mulder, M., Wesselink, R., 2004. Competence-based VET in the Netherlands: backgrounds and pitfalls. J. Vocat. Educ. Train. 56 (4), 523-538.

Billett, S., 1994. Situated learning - a workplace experience. Aust. J. Adult Community Educ. 34 (2), 112-130.

Blok, V., 2013. The power of speech acts: reflections of performative concepts of ethical oaths in economics and business. Rev. Soc. Econ. 71 (2), 187-208.

Blok, V., Sjauw-Koen-Fa, A., Omta, O., 2013. Effective stakeholder involvement at the base of the pyramid: the case of rabobank. Int. Food Agribus. Manag. Rev. 16A, 39-44.

Boyatzis, R.E., 1982. The Competent Manager: a Model for Effective Performance. Wiley, New York.

Brown, J.S., Collins, A., Duguid, S., 1989. Situated cognition and the culture of learning. Educ. Res. 18 (1), 32-42.

Cheetham, G., Chivers, G., 1996. Towards a holistic model of professional competence. J. Eur. Ind. Train. 20 (5), 20-30.

Dahlsrud, A., 2008. How corporate social responsibility is defined: an analysis of 37 definitions. Corp. Soc. Responsib. Environ. Manag. 15 (1), 1-13.

De Colle, S., Henriques, A., 2013. The paradox of corporate social responsibility standards. J. Bus. Ethics. http://dx.doi.org/10.1007/s10551-013-1912-y.

De Haan, G., 2010. The development of ESD-related competencies in supportive institutional frameworks. Int. Rev. Educ. 56, 315-328.

Dentoni, D., Blok, V., Lans, T., Wesselink, R., 2012. Developing human capital for agri-food firms' multi-stakeholder interactions. Int. Food Agribus. Manag. Rev. $15,61-68$.

Dubois, D., Rothwell, W., 2004. Competency-based or a traditional approach to training? ProQuest Educ. J. 58 (4), 46-58.

Dunphy, D., Griffiths, A., Benn, S., 2003. Organisational Change for Corporate Sustainability. Routledge, London.

Ellis, G., Weekes, T., 2008. Making sustainability 'real': using group-enquiry to promote education for sustainable development. Environ. Educ. Res. 14, $482-500$.

Eraut, M., 1994. Developing Professional Knowledge and Competence. Falmer Press, London.

European Commission, 2001. Promoting a European Framework for Corporate Social Responsibility. Green Paper. European Commission.

Fisher, R.J., 1993. Social desirability bias and the validity of indirect questioning. J. Consumer Res. 20, 303-315.

Glaser, B., Strauss, A.L., 1967. The Discovery of Grounded Theory: Strategies for Qualitative Research. Aldine Publishing Company, Chicago.

Gonczi, A., 1994. Developing a Competent Workforce. National Centre for Vocational Education Research, Adelaide.
Gunningham, N., Kagan, R.A., Thornton, D., 2004. Social license and environmental protection: why businesses go beyond compliance. Law Soc. Inq. 29 (2), 307-341.

Hamann, R., Giamporcaro, S., Johnston, D., 2011. The role of business and crosssector collaboration in addressing the 'wicked problem' of food insecurity. Dev. South. Afr. 28 (4), 579-597.

Heaton, J., 2002. Reworking Qualitative Data. Sage, London.

Hesselbarth, C., Schaltegger, S., 2014. Educating change agents for sustainability learning from the first sustainability management master of business administration. J. Clean. Prod. 62, 24-36.

Hinds, P.S., Vogel, R.J., Clarke-Steffen, L., 1997. The possibilities and pitfalls of doing a secondary analysis of a qualitative data set. Qual. Health Res. 7 (3), 408-424.

Hodkinson, P., Issitt, M., 1995. The Challenge of Competence: Professionalism through Vocational Education and Training. Cassell, London.

Kaptein, M., Wempe, J., 2002. The Balanced Company. A Theory of Corporate Integratie. Oxford University Press, Oxford.

Lambrechts, W., Mulà, I., Ceulemans, K., Molderez, I., 2013. The integration of competences for sustainable development in higher education: an analysis of bachelor programs in management. J. Clean. Prod. 48, 65-73.

Lans, T., Blok, V., Wesselink, R., 2014. Learning apart together: towards an integrated framework for sustainable entrepreneurship competence in higher education. J. Clean. Prod. 62, 37-47.

Lievens, F., Sanchez, J.I., De Corte, W., 2004. Easing the inferential leap in competency modelling: the effects of task-related information and subject matter expertise. Pers. Psychol. 57, 881-904.

Lozano, R., 2008. Envisioning sustainability three-dimensionally. J. Clean. Prod. 16 $1838-1846$.

Lozano, R., 2012. Towards better embedding sustainability into companies' systems: an analysis of voluntary corporate initiatives. J. Clean. Prod. 25, 14-26.

Maon, F., Lindgreen, A., Swaen, V., 2009. Designing and implementing corporate social responsibility: an integrative framework grounded in theory and practice. J. Bus. Ethics 87, 71-89.

Marrewijk, M. van, Werre, M., 2003. Multiple levels of corporate sustainability. J. Bus. Ethics 44, 107-119.

McLagan, P.A., 1989. Models for HRD Practice. The Models. American Society for Training and Development, Alexandria.

Mulder, M., 2014. Conceptions of professional competence. In: Billett, S., Harteis, C., Gruber, H. (Eds.), International Handbook on Research into Professional and Practice-based Learning. Springer, Dordrecht.

Mulder, M., 2001. Competentie Ontwikkeling in Organisaties (Competence development in Organisations). Elsevier Bedrijfsinformatie, Den Haag.

Mulder, M., Wesselink, R., Bruijstens, J., Chr, J., 2005. Job profile research for the purchasing profession. Int. J. Train. Dev. 9 (3), 185-204.

Mogensen, F., Schnack, K., 2010. The action competence approach and the 'new' discourses of education for sustainable development, competence and quality criteria. Environ. Educ. Res. 16 (1), 59-74.

O'Riordan, L., Fairbrass, J., 2013. Managing CSR stakeholder engagement: a new conceptual framework. J. Bus. Ethics. http://dx.doi.org/10.1007/s10551-0131913-x.

Peterson, C., 2009. Transformational supply chains and the 'wicked problem' of sustainability: aligning knowledge, innovation, entrepreneurship, and leadership. J. Chain Netw. Sci. 9, 71-82.

Rieckmann, M., 2012. Future-oriented higher education: which key competencies should be fostered through university teaching and learning. Futures 44, 127-135.

Rothaermel, F.T., Hess, A.M., 2007. Building dynamic capabilities: innovation driven by individual-, firm-, and Netwerk-level effects. Organ. Sci. 18 (6), 898-921.

Sandberg, J., 2000. Understanding human competence at work: an interpretative approach. Acad. Manag. J. 43 (1), 9-25.

Schnack, K., 1996. Internationalisation, democracy and environmental education. In: Breiting, S., Nielsen, K. (Eds.), Environmental Education Research in the Nordic Countries: Proceedings from the Research Centre for Environmental and Health Education. The Royal Danish School for Educational Studies, Copenhagen, pp. 7-19.

Schwartz, B., Tilling, K., 2009. 'ISO-lating' corporate social responsibility in the organizational context: a dissenting interpretation of ISO26000. Corp. Soc. Responsib. Environ. Manag. 16, 289-299.

Selsky, J.W., Parker, B., 2005. Cross-sector partnerships to address social issues: challenges to theory and practice. J. Manag. 31, 849-873.

Smith, E., 2008. Pitfalls and promises: the use of secondary data analysis in educational research. Br. J. Educ. Stud. 56 (3), 323-339.

Van Kleef, J.A.G., Room, N.J., 2007. Developing capabilities and competence for sustainable business management as innovation: a research agenda. J. Clean. Prod. 15, 38-41.

Veldhuizen, M.T., Blok, V., Dentoni, D., 2013. Organisational drivers of capabilities for multi-stakeholder dialogue and knowledge integration. J. Chain Netw. Sci. (forthcoming).

Wals, A.E.J., 2010. Mirroring, gestaltswitching and transformative social learning: stepping stones for developing sustainable competence. Int. J. Sustain. High. Educ. Policy 15, 121-131.

Wals, A.E.J., 2014. Sustainability in higher education in the context of the UN DESD: a review of learning and institutionalization processes. J. Clean. Prod. 62, 8-15. 
Wiek, A., Withycombe, L., Redman, C.L., 2011. Key competencies in sustainability: a reference framework for academic program development. Sustain. Sci. 6, 203-218.

Willard, M., Wiedmeyer, C., Warren Flint, R., Weedon, J.S., Woodward, R., Feldman, I., Edwards, M., 2010. The sustainability professional: 2010 competency survey report. Environ. Qual. Manag. 49-83.
Wilson, A., Lenssen, G., Hind, P., 2006. Leadership Qualities and Management Competencies for Corporate Responsibility. Ashridge, United Kingdom.

Yin, R.K., 2002. Case Study Research: Design and Methods (3rd ed.). Sage, Thousand Oaks, CA.

Yin, R.K., 2009. Case Study Research: Design and Methods, vol. 5. Sage, California. 